WHC-MR-0418

Revision 0

UC-630

\title{
Historical Records of Radioactive Contamination in Biota at the 200 Areas of the Hanford Site
}
A. R. Johnson
B. M. Markes
J. W. Schmidt
A. N. Shah
S. G. Weiss
K. J. Wilson

Date Published

June 1994

Prepared for the U.S. Department of Energy Office of Environmental Restoration and Waste Management

\footnotetext{
(2) Westingthouse

P.O. Box 1970

Hanford Company Richland, Washington 99352

Hanford Operations and Engineering Contractor for the

U.S. Department of Energy under Contract DE-AC06-87RL10930
} 


\section{RELEASE AUTHORIZATION}

Document Number: WHC-MR-0418, Rev. 0

Document Title: Historical Records of Radioactive Contamination in Biota at the 200 Areas of the Hanford Site

Release Date: $\quad 6 / 28 / 94$

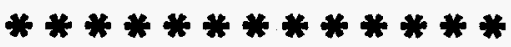

This document was reviewed following the procedures described in WHC-CM-3-4 and is:

\section{APPROVED FOR PUBLIC RELEASE}

$* * * * * * * * * * * * *$

WHC Information Release Administration Specialist:

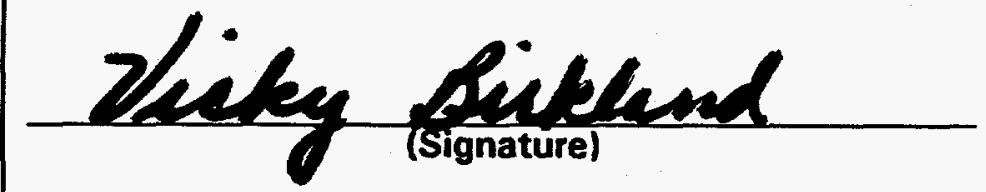

$6 / 28 / 94$

(Date) 


\section{DISCLAIMER}

This report was prepared as an account of work sponsored by an agency of the United States Government. Neither the United States Government nor any agency thereof, nor any of their employees, make any warranty, express or implied, or assumes any legal liability or responsibility for the accuracy, completeness, or usefulness of any information, apparatus, product, or process disclosed, or represents that its use would not infringe privately owned rights. Reference herein to any specific commercial product, process, or service by trade name, trademark, manufacturer, or otherwise does not necessarily constitute or imply its endorsement, recommendation, or favoring by the United States Government or any agency thereof. The views and opinions of authors expressed herein do not necessarily state or reflect those of the United States Government or any agency thereof. 


\section{DISCLAIMER}

Portions of this document may be illegible in electronic image products. Images are produced from the best available original document. 
WHC-MR-0418 REV 0

Document Title: Historical Records of Monitoring Radioactive Contamination in Biota at the 200 Areas of the Hanford Site

Prepared by:

Reviewed and approved by:

Approved by:
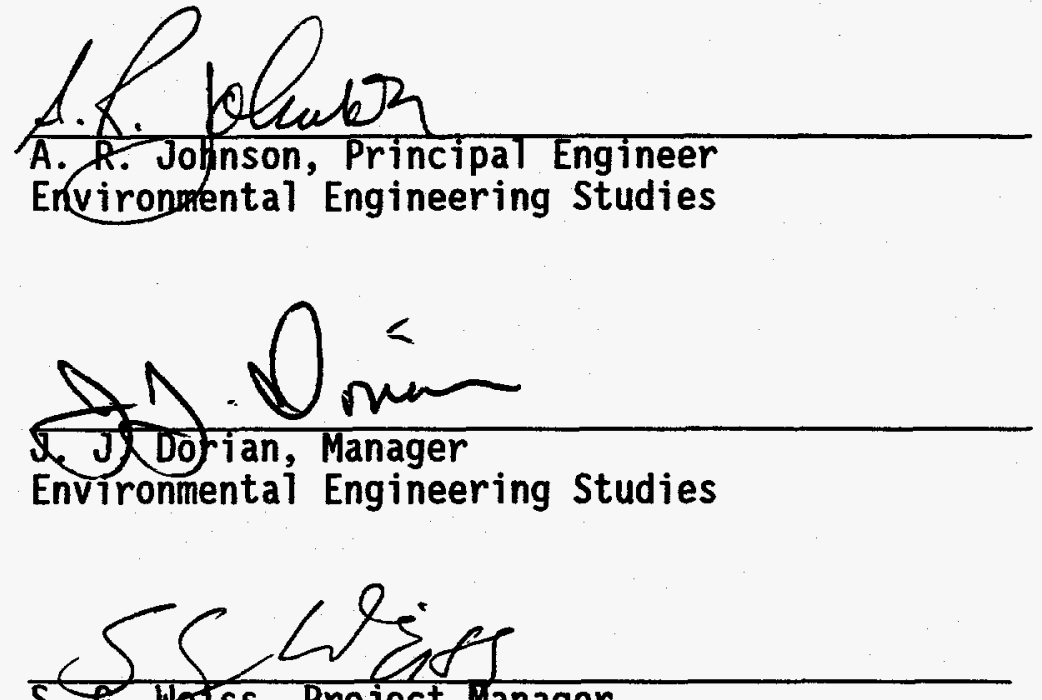

S. G. We ss, Project manager

Environmental Restoration Engineering $\frac{60.24 .94}{\text { Date }}$

$\frac{6 / 24 / 94}{\text { Date }}$

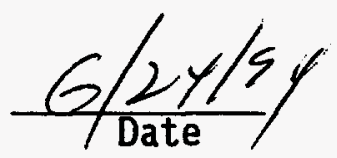


WHC-MR-0418, REV 0

This page intentionally left blank. 
WHC-MR-0418, REV 0

\section{EXECUTIVE SUMMARY}

This document summarizes and reports a literature search of 85 environmental monitoring records of wildlife and vegetation (biota) at the 200 East Area and the 200 West Area of the Hanford Site since 1965. These records were published annually and provided the majority of the data in this report. Additional sources of data have included records of specific facilities, such as site characterization documents and preoperational environmental surveys. These documents have been released for public use. Records before 1965 were still being researched and therefore not included in this document. The intent of compiling these data into a single source was to identify past and current concentrations of radionuclides in biota at specific facilities and waste sites within each operable unit that may be used to help guide cleanup activities in the 200 Areas to be completed under the Comprehensive Environmental Response and Liability Act (CERCLA).

The 200 East Area and 200 West Area were the locations of the Hanford Site separation and process facilities and waste management units. These Areas, consisting of about $40 \mathrm{~km}^{2}$, were centrally located within the Hanford Site about $10 \mathrm{~km}$ south of the Columbia River and $30 \mathrm{~km}$ northwest of Richland, Washington (Figure 1).

For the purposes of this document, a sample was of interest if a GeigerMueller counter equipped with a pancake probe indicated beta/gamma emitting radioactivity above 200 counts per minute (cpm), or if laboratory radioanalyses indicated a radionuclide concentration equaled or exceeded 10 picocuries per gram $(\mathrm{pCi} / \mathrm{g})$. About 4,500 individual cases of monitoring for radionuclide uptake or transport in biota in the 200 Areas environs were included in the documents reviewed. About 1,900 (i.e., 42\%) of these biota had radionuclide concentrations in excess of $10 \mathrm{pCi} / \mathrm{g}$. These radionuclide transport or uptake cases were distributed among 45 species of wildlife (primarily small mammals and feces) and 30 species of vegetation. The wildlife species most commonly associated with radioactive contamination were the house mouse and the deer mouse and of vegetation species, the Russian thistle.

The data showed that the highest radionuclide concentration in vegetation was in Russian thistle $(3.2 \mathrm{E}+06 \mathrm{pCi} / \mathrm{g}$ of strontium-90) in 1981 at the 216-BC Cribs. As a comparison, the WHC strontium-90 soil standard for releasing an area from radiological controls in the 200 Areas is $2.8 \mathrm{E}+03$ $\mathrm{pCi} / \mathrm{g}$. Since 1965 , there have been about 1,100 cases of radionuclide uptake by vegetation in the 200 Areas that resulted in radioactivity greater than 200 $\mathrm{cpm}$ or in concentrations greater than $1.0 \mathrm{E}+01 \mathrm{pCi} / \mathrm{g}$. The highest radionuclide concentration in wildlife $(6.6 \mathrm{E}+10 \mathrm{pCi} / \mathrm{g}$ of strontium-90) was in a house mouse from 241-BX Tank Farm in 1991. Since 1965, there have been about 830 cases of radionuclide uptake by wildlife, nearly all small mammals or feces, in the 200 Areas that resulted in concentrations greater than $1.0 \mathrm{E}+01 \mathrm{pCi} / \mathrm{g}$. Forty-two of the 50 highest radionuclide concentrations found in biota in the 200 Areas since 1965 have been in these animals or feces, and the highest 10 concentrations have all been in animals or feces. Comparison of the data showed that of about 2,400 biotic samples collected during routine monitoring from throughout the 200 Areas, only about 120 exceeded $1.0 \mathrm{E}+01 \mathrm{pCi} / \mathrm{g}$ concentration (i.e., about 5\%). Of about 2,100 biotic samples collected 
during special investigations at known contaminated locations, about 1,800 exceeded concentrations of $1.0 E+01 \mathrm{pCi} / \mathrm{g}$ (i.e., about $86 \%$ ).

The monitoring data indicated that radionuclide contamination had remained relatively localized even though it had spread beyond waste site boundaries. The Hanford Site Environmental Surveillance Program (SESP), which routinely monitors known pathways to man, rarely detected radionuclide concentrations above $1.0 \mathrm{E}+01 \mathrm{pCi} / \mathrm{g}$ beyond the operations areas of the Hanford Site. Conversely, the Operational Environmental Monitoring Program (OEMP), which monitors effiuent controls, routinely detected contamination at some waste sites. When the SESP and the OEMP indicated elevated concentrations of radionuclides, interim stabilization of those locations was initiated in many instances. Noticeable improvements in reducing uptake and transport of radionuclides by biota were evident from those areas that had been interim stabilized, such as the 216-A-24 Crib, 216-A-25 Pond, 216-B-1, -2, and -3 Ditches, the 216-S Ponds, 216-U-10 Pond, and BC Cribs. Other historical sources of radionuclide uptake, including the Cross-country Transfer Line, 244-A Lift Station, 216-A-40 Basin, and the 216-B-3 Pond were being interim stabilized in 1994. Routine surveys to detect radioactivity at the waste sites are part of the OEMP and act as a trigger to indicate the need for special investigative sampling and possibly additional stabilization.

Comparisons among the facility and waste site locations were limited because of variation among the studies reported by the reviewed documents (i.e., intent, methodology, sample composition, and laboratory). It was often not possible to establish relationships between a site's potential for contamination and concentrations observed in biota beyond ident ifying contaminated areas of known access to biota so that information may be used to help in cleanup decisions. The data do seem to indicate an overall downward trend in many areas for both numbers of biota uptaking radionuclides and levels of uptake. This reduction may be a result of decrease in radionuclide half-lives over time (however, the radionuclides reported in the Appendix are al1 long-lived), cessation of operation activities, or improved barriers to biotic intrusion. Most likely a combination of these factors was responsible for the trends. 
WHC-MR-0418, REV 0

TABLE OF CONTENTS

EXECUTIVE SUMMARY .................... v

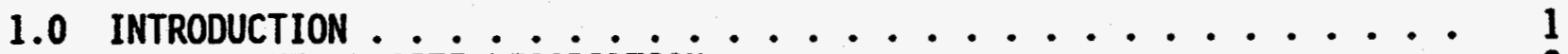

1.1 HANFORD SITE DESCRIPTION .............. 2

1.2200 AREAS DESCRIPTION ................ 2

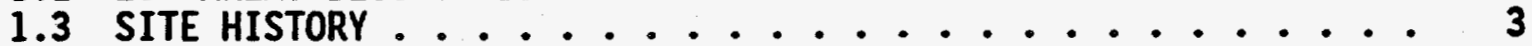

2.0 WASTE FACILITY AND DISPOSAL SITE DESCRIPTION . . . . . . . 7

2.1 CRIBS ........................... 7

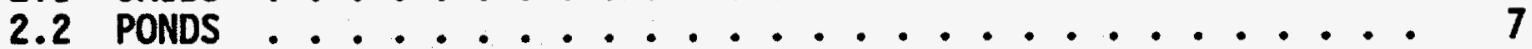

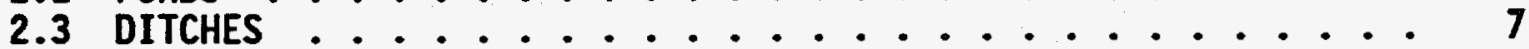

2.4 FRENCH DRAINS AND REVERSE WELLS ........... 8

2.5 SOLID WASTE DISPOSAL SITES ............. 8

3.0200 EAST AREA PROCESSING FACILITIES ............. 9

3.1 A PLANT - PLUTONIUM-URANIUM EXTRACTION FACILITY (PUREX) . . . 9

$3.2242-A$ EVAPORATOR . . . . . . . . . . . . . . 9

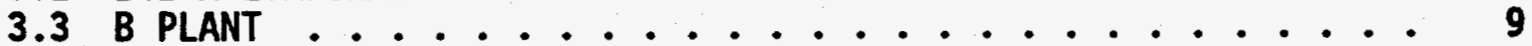

3.4 C PLANT - STRONTIUM SEMIWORKS (HOT SEMIWORKS) ....... 9

3.5 GROUT FACILITY . . . . . . . . . . . . . 9

4.0200 WEST AREA PROCESSING FACILITIES ............ 11

4.1 S PLANT - REDOX AND 222-S LABORATORY COMPLEX . . . . . ... 11

$4.2242-S$ EVAPORATOR . . . . . . . . . . . . . 11

4.3 T PLANT ............................. 11

4.4 U PLANT AND UO ${ }_{3}$ - URANIUM OXIDE PLANT $\ldots \ldots \ldots \ldots$

4.5 Z PLANT - PLUTONIUM FINISHING PLANT ............ 12

4.6 SOLID WASTE COMPACTOR FACILITY ............ 12

4.7 2724-W PROTECTIVE EQUIPMENT DECONTAMINATION FACILITY (PEDF) • 12

4.8 CENTRAL WASTE COMPLEX ............... 12

5.0 WASTE TREATMENT AND MANAGEMENT FACILITIES . . . . . . . . 13

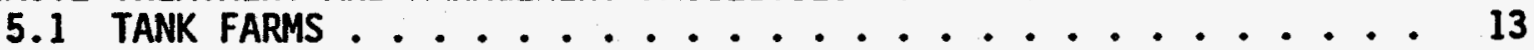

5.2 LOW-LEVEL BURIAL GROUNDS ............... 13

6.0 RADIOACTIVELY CONTAMINATED AREA . . . . . . . . . . 15

6.1 CURRENT KNOWN TERRESTRIAL BIOTA CONTAMINATION ....... 15

6.2 CURRENT KNOWN RIPARIAN AREA AND BIOTA CONTAMINATION $\ldots \ldots . .16$

6.3 CONTAMINATION SUMMARY ............... 17

7.0 CONTAMINANTS OF CONCERN ................. 19

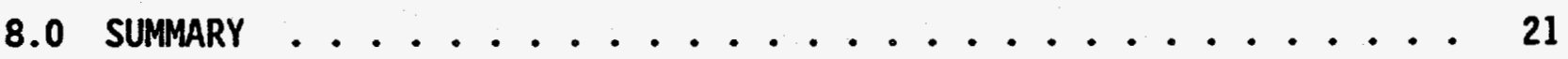

9.0 REFERENCES ....................... 25

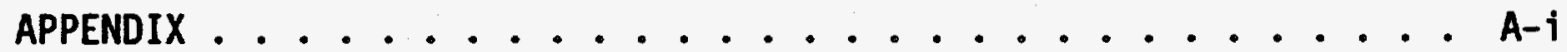


WHC-MR-0418, REV 0

\section{LIST OF FIGURES}

1. Location of the Hanford Site ................... 4

2. The 200 East Area . . . . . . . . . . . . . . . . . 5

3. The 200 West Area ........................ . . 6

\section{LIST OF TABLES}

1. Categories and Numbers of Waste Units on the Hanford Site (1993) . . . . . . . . . . . . . . . 8

2. Radioactive Contaminated Acres at the Hanford Site . . . . . . . 15 


\subsection{INTRODUCTION}

Westinghouse Hanford Company (WHC) is the Operations and Engineering Contractor for the U.S. Department of Energy (DOE) at the Hanford Site. WHC is currently responsible for managing active facilities and remediation of the inactive fuel reprocessing and radioactive waste management facilities in the 200 East and 200 West Areas. Beginning July 1, 1994 another contractor, Bechtel Hanford Incorporated (BHI), will assume responsibility for designated surplus facilities and waste sites. An operational, environmental monitoring program to ensure operational control, includes collecting biotic inhabitants of these reprocessing and waste management facilities and sites and having radionuclide analyses performed to measure the effectiveness of effluent controls and waste disposal barriers. In addition to the facility-specific operational monitoring program, there is a site environmental surveillance program operated for DOE by Battelle Pacific Northwest Laboratory. These monitoring programs have produced annual environmental reports as well as several special studies. This document includes a compilation of animal and vegetation (biota) monitoring results since 1965 in the 200 Areas. The data are presented in a single Appendix that is on computer disk as a Wordperfect file. The data will also be entered into the ARCINFO and HEISS data bases.

It is necessary to understand the scope of environmental monitoring and surveillance at the Hanford Site to better understand the data in the Appendix. The Hanford Site Environmental Surveillance Program (SESP), operated by PNL, monitors from on and off the Hanford Site for potential chemical and radiological contaminants originating from Hanford Site operations (Woodruff et al. 1993). The media sampled included air, surface water, soil, vegetation, wildlife, food and farm products, external radiation levels, and groundwater. This program monitors environmental pathways potentially having far-field or offsite impacts and helps determine the dose to man resulting from Hanford Site operations. A second program, operated for DOE by WHC, is called the Operational Environmental Monitoring Program (OEMP) and monitors air, soil, vegetation, resident animals, surface water, external radiation levels, and groundwater. The purpose of the OEMP is to determine performance of radioactive waste confinement systems, and to monitor trends of radioactive materials in the operations environment adjacent to nuclear facilities and waste disposal facilities. It is notable that while the OEMP monitoring detects significant levels of radionuclide uptake in some biota, the SESP detects relatively little. These differences are evident when comparing the annual data reports of the two programs or the summary included in the annual Hanford Site Environmental Report.

The waste management sites are intended for low maintenance. Biological barriers were an integral part of these sites, but they have varied widely in their design. Barrier design has evolved from applying about $15 \mathrm{~cm}$ of soil over radioactive waste to using engineered multilayered barriers in some

instances. The less stringent past practices have often resulted in biological intrusion into radioactive material that requires routine monitoring and eventual cleanup. In contrast, the process facilities are areas of high use, and therefore, are not easily or fully protected against the intrusion of biota. The result was that these sites have also been the source of contamination spread, often by biota. 
WHC-MR-0418, REV 0

\subsection{HANFORD SITE DESCRIPTION}

The Hanford Site, which currently consists of 1,476 square kilometers $\left(\mathrm{km}^{2}\right)$ in southcentral Washington, was established in 1943 as a national security area to produce plutonium used in nuclear weapons (Figure 1). In 1968, the Atomic Energy Commission designated $311 \mathrm{~km}^{2}$ of the area as an Arid Lands Ecology Reserve. During the $1970 \mathrm{~s}$, about $130 \mathrm{~km}^{2}$ north of the Columbia River were leased to the United States Fish and Wildlife Service for the Saddle Mountain National Wildlife Refuge, and about $200 \mathrm{~km}^{2}$ north and east of the river were leased to the Washington Department of Game for outdoor recreation. In 1977, the Hanford Site was designated as a National Environmental Research Park by the United States Energy Research and Development Administration. The Hanford Site is one of the few large areas of land in the region that has not been developed for modern agricultural use. It was also unique in that the general public's use of the area was very restricted and since 1943 has been limited to projects associated with the nuclear industry. The Hanford Site is bounded on the north by the Saddle Mountains, on the east by the Columbia River, and on the south and west by the Yakima River and Rattlesnake Hills, respectively. The dominant topographical features of the Hanford Site include the Rattlesnake Hills (elevation $1,090 \mathrm{~m})$, the Columbia River, and associated aquatic habitats, unstabilized sand dunes near the Columbia River, basaltic ridges that interrupt the rolling landscape of the Site, and the 200 Areas plateau (elevation $200 \mathrm{~m}$ ), which is the location of the most manmade perturbations.

The Hanford Site climate is one of the hottest and driest in the Pacific Northwest. The climate is strongly influenced by the Cascade Mountain Range to the west, which forms a barrier to moisture-laden storms from the Pacific Ocean. July is the hottest and driest month, and January is the coldest and wettest. Annual precipitation averages slightly less than $17.8 \mathrm{~cm}$ with $42 \%$ of that amount falling between November and January. The average annual

temperature is $11.7^{\circ} \mathrm{C}$; temperatures in excess of $38^{\circ} \mathrm{C}$ and below $0{ }^{\circ} \mathrm{C}$ are common.

The Hanford Site has been classified primarily as a shrub-steppe grassland and is composed of a variety of plant communities (Daubenmire 1970). Major plant species include sagebrush (Artemisia tridentata), bitterbrush (Purshia tridentata), Sandberg's bluegrass (Poa sandbergii), cheatgrass (Bromus tectorum), and rabbitbrush species (Chrysothamnus sp.). The principal bodies of water associated with the Hanford Site include the last free-flowing stretch of the Columbia River in the United States, Rattlesnake Springs, a naturally occurring pond called West Lake, and several ponds and ditches that result from the operation of nuclear facilities. The Columbia River is not only an important salmon, steelhead, and bass fishery; its many islands al so serve as nesting grounds for Canada Geese and other waterfowl. A11 the ponds but West Lake and all the ditches were created from man's activities and attract many wildlife species, particularly birds. The total aquatic habitat aside from that provided by the Columbia River system is about $57 \mathrm{ha}$.

\subsection{AREAS DESCRIPTION}

The 200 Areas nuclear fuel reprocessing facilities and waste management units, consist of about $40 \mathrm{~km}^{2}$ and are centrally located within the Hanford Site about $10 \mathrm{~km}$ south of the Columbia River and $30 \mathrm{~km}$ northwest of Richland, 
Washington (Figure 1). The 200 East and 200 West Areas 1ie on a plateau in the central part of the Hanford Site. The two areas are the locations of various waste process facilities and waste disposal facilities, such as liquid waste cribs, ponds, ditches, tank farms, and solid waste burial grounds (Figures 2 and 3 ).

The ecology of the 200 Areas was originally typical shrub-steppe desert characterized by such vegetation as big sagebrush (Artemisia tridentata) and Sandberg's bluegrass (Poa sandbergii). Extensive tracts of this habitat exist just outside of the 200 Areas; however, the approximately 2,000 hectares ( 9 square miles) within the two 200 Areas has been mostly disturbed and varies greatly from introduced bunchgrasses (Agropyron spp.), Russian thistle (Salsola kali) and rabbitbrush (Chrysothamnus spp.), to riparian species along the manmade ditches and ponds, such as willow (Salix spp.), cattail (Typha latifolia), and cottonwood (Populus spp.). The manmade, contaminated riparian sites have been or are in the process of being interim stabilized so that riparian vegetation will not be found in the 200 Areas except at the naturally occurring West Lake, the Steam Plant cooling ponds, and "C" Lobe of 216-B-3 Pond. The wildlife species of the 200 Areas have remained similar to those found before human use of the plateau except for certain introduced species that took advantage of the changed habitats. Native species have included such species as the long-billed curlew (Numenius americanus), the horned 1ark (Eremiphila alpestris), the burrowing owl (Athene cunicularia), the sage sparrow (Amphispiza belli), the loggerhead shrike (Lanius ludovicianus), the Great Basin pocket mouse (Perognathus parvus), the deer mouse (Peromyscus maniculatus), the Western harvest mouse (Reithrodontomys megalotis), the black-tailed jackrabbit (Lepus californicus), the badger (Taxidea taxis), and the coyote (Canis latrans). Species taking advantage of the altered habitats have included several waterfowl species (family Anatidae), the domestic pigeon (Columba livia), and the house mouse (Mus musculus).

\subsection{SITE HISTORY}

The Hanford Site was acquired by the federal government in 1943 for the construction and operation of facilities to produce plutonium for the atomic weapons program during World War II. For about forty years Hanford Site facilities were dedicated primarily to the production of plutonium for national defense, and management of the wastes generated by chemical processing operations. Since 1987, programs at the Hanford Site have become increasingly diverse, involving research and development for advanced reactors, renewable energy technologies, waste disposal technologies, and cleanup of contaminated areas from past practices. While some of these areas have been interim stabilized, the potential may exist for reoccurrence of biotic uptake and transport.

Radionuclide uptake by vegetation and wildlife (biota) has been documented in repeated cases since nuclear operations began at Hanford. Many of these data have been published in monthly and annual environmental reports developed by several of the various Hanford Site contractors. However, there was no single document that depicted what had occurred during monitoring to detect biotic uptake of radionuclides. 


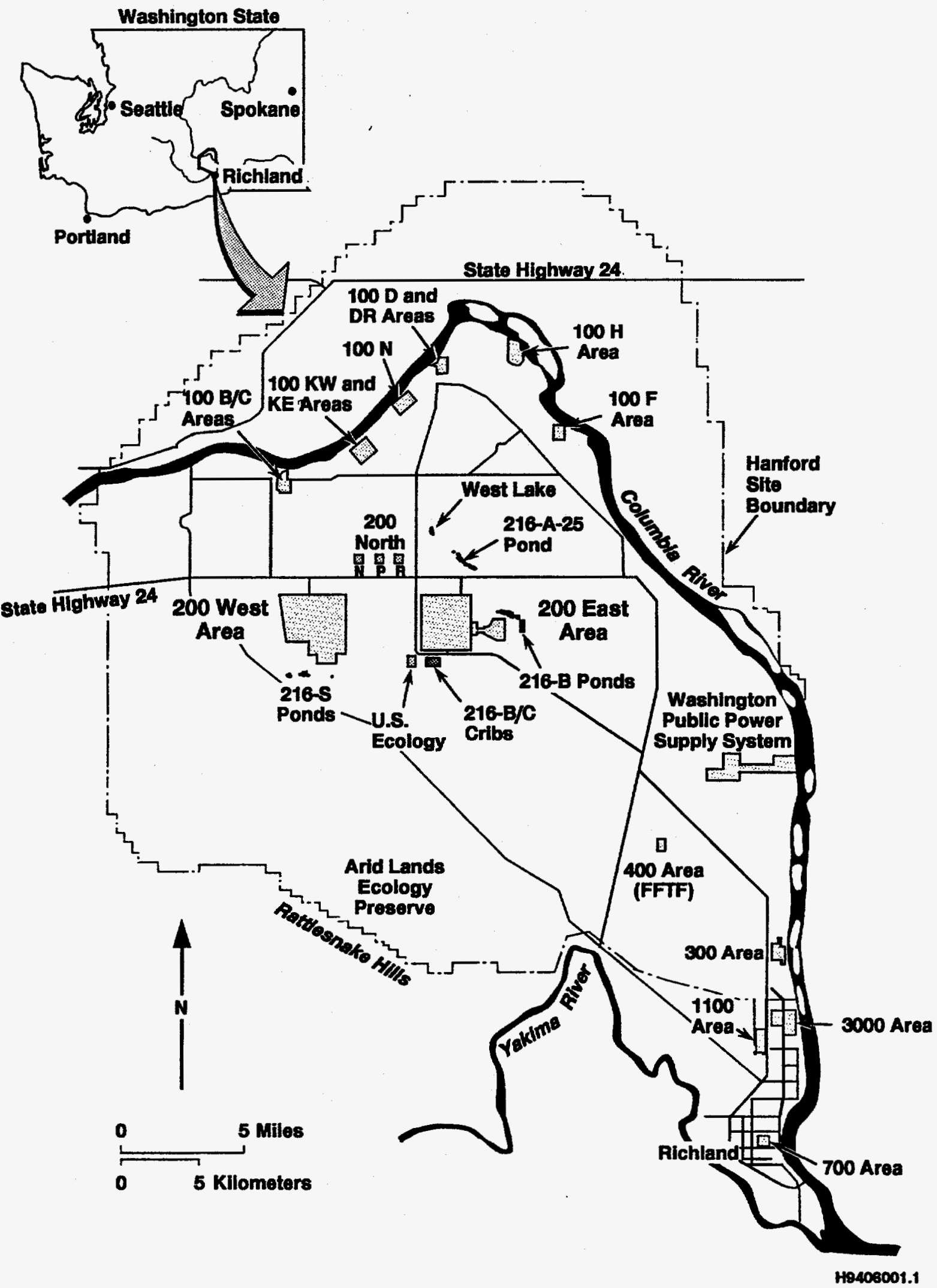

Figure 1. Location of the Hanford Site. 


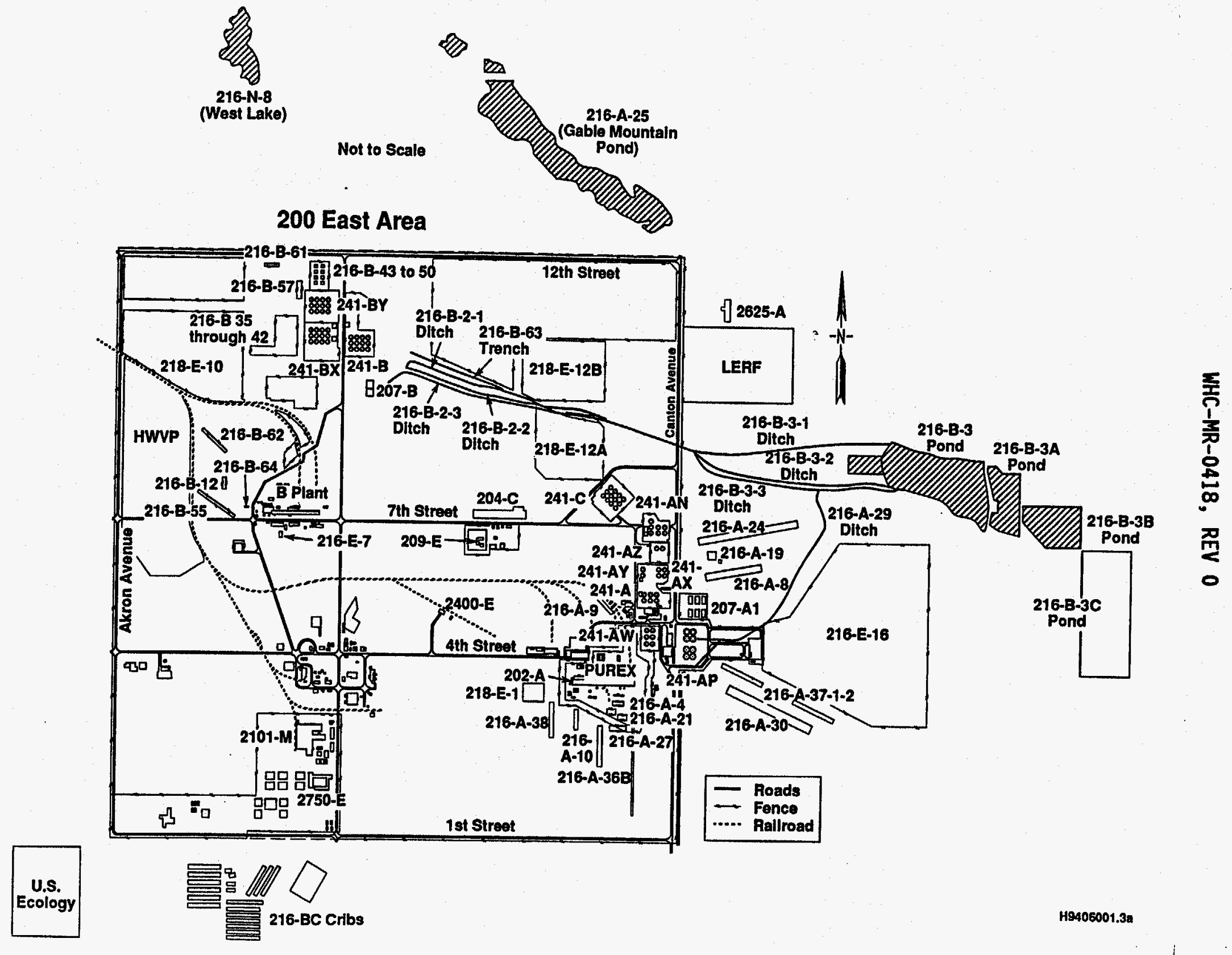




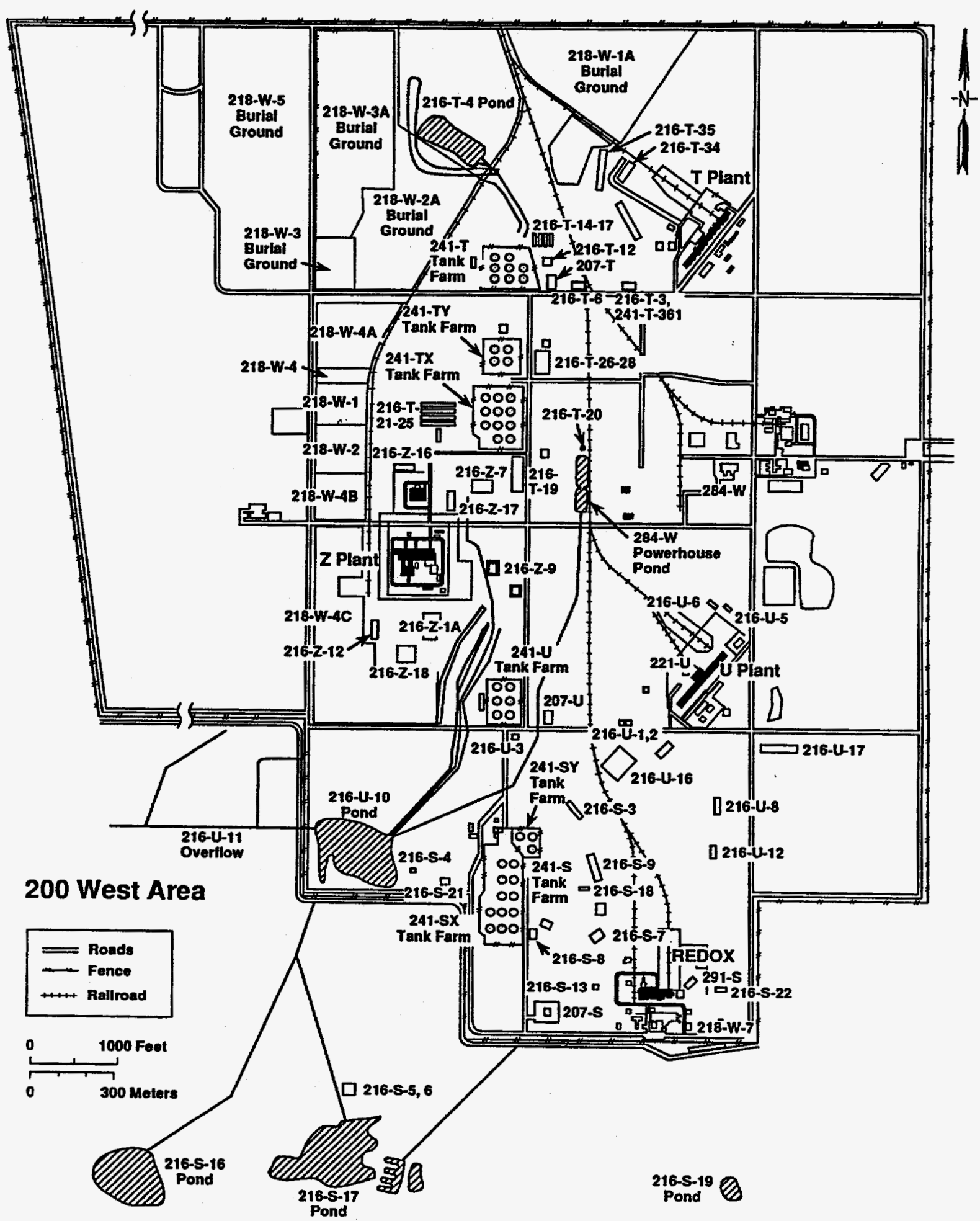

H9406001.2

Figure 3. The 200 West Area. 
WHC-MR-0418, REV 0

\subsection{WASTE FACILITY AND DISPOSAL SITE DESCRIPTION}

The Hanford Site has used 14 types of waste handling and disposal facilities (Table 1). These are listed in the following tables and include cribs, ponds, ditches, french drains (sometimes called injection wells or reverse wells), and solid waste disposal sites such as burial grounds. These process facilities may be operating, placed on stand-by, or inactive.

The way radionuclides got into the biota or were transported through the environment by biota varied. Some radioactive wastes were actively sought by biota (e.g., small mammals burrowed into the waste for the salt content) and some were merely transported because it was present in the biotic environment (e.g., waste adhering to the fur of small mammals). Relatively low concentrations and quantities of low-level radioactive liquid wastes in open systems, such as ditches and ponds, contributed to direct uptake by wildlife that used the open water for drinking (e.g., mice, rabbits, and deer) or for cover and resting areas (e.g., waterfowl). Higher concentrations of low-level radioactive liquid waste disposed to closed systems, such as cribs and solid waste, disposed to trenches or burial grounds reentered the surface environment through uptake by deep-rooted vegetation (e.g., Russian thistle also called tumbleweeds). This vegetation could then die, be uprooted, be eaten by wildlife, or be consumed by burrowing wildlife that sought out some of the waste for its salt content.

\subsection{CRIBS}

Low-level liquid waste was discharged to the ground via structures called cribs. These subsurface systems allow the liquid component of the waste to percolate into the soil. The natural properties of the soil were used to remove radioactive material from the effluent water through

filtration, ion exchange, and precipitation reactions. Most of the cribs were vented to the atmosphere through engineered vents and pipe risers. These engineered structures were in place to promote downward flow of liquids disposed of in these cribs.

\subsection{PONDS}

Ponds were used to manage the large quantities of water (i.e., cooling water and steam condensate) associated with chemical processing operations. These liquid effluents were normally uncontaminated except for some upset conditions at the facilities. The ponds percolated liquid effluent into the soil column.

\subsection{DITCHES}

A ditch was an open, unlined excavation used to dispose liquid effluents or transport liquid effluents to ponds for disposal. Normally these liquids were uncontaminated except for upset conditions at the facilities. Open ponds and ditches have served as attractions for wildlife species. 


\subsection{FRENCH DRAINS AND REVERSE MELLS}

French drains or reverse wells were culverts inserted vertically into the ground to dispose of liquid waste by percolation into the soil and using natural filtration to remove radionuclides. They were of varying depth (1 to $92 \mathrm{~m}$ ) and the shallow ones were filled with rock.

\subsection{SOLID WASTE DISPOSAL SITES}

Solid wastes were buried in shallow trenches. Packaging procedures and burial practices depended on the type of waste.

Table 1. Categories and Numbers of Waste Units on the Hanford Site (1993).

\begin{tabular}{|c|c|c|}
\hline Major type of waste unit & Active & Inactive \\
\hline Single-shell tanks & 0 & 149 \\
\hline Double-shell tanks & 28 & 0 \\
\hline Cribs and drain fields & 16 & 115 \\
\hline Trenches & 1 & 88 \\
\hline Ponds & 13 & 18 \\
\hline Ditches & 7 & 14 \\
\hline Reverse wells & 0 & 11 \\
\hline French drains & 21 & 47 \\
\hline $\begin{array}{c}\text { Engineered liquid disposal } \\
\text { unit (Sum) }\end{array}$ & 58 & 293 \\
\hline Spills & 0 & 229 \\
\hline Burial grounds & 9 & 68 \\
\hline Landfills & 2 & 10 \\
\hline Demolition and inert \\
landfills & 5 & 2 \\
\hline Burn pits & 0 & 22 \\
\hline
\end{tabular}




\subsection{EAST AREA PROCESSING FACILITIES}

\subsection{A PLANT - PLUTONIUM-URANIUN EXTRACTION FACILITY (PUREX)}

The PUREX Plant spent fuel processing system is located in the 200 East Area and operated from 1956 unti7 1972. It was on standby for upgrades from 1972 until 1983 when operations again commenced. PUREX operated intermittently until 1993, and operations have now ceased. The facility is being prepared for decommissioning. Wastes have gone to several cribs, ditches, and ponds (those with 216-A designations) burial grounds in the 200 East Area (those with 218-E designations), as well as to 216-A-25 Pond and 216-B-3 Pond. Solid wastes were sent to the 218-E Burial Grounds.

\subsection{2-A EVAPORATOR}

The 242-A Evaporator complex processes and separates liquid wastes from PUREX. The 242-A Building is located south of the 241-A and 241-AX Tank Farms and north of the 242-AW Tank Farm.

\subsection{B PLANT}

The B Plant commenced in 1945 and was originally designed to chemically process spent nuclear fuels. It operated in that mode until 1952. More recently this has been the site of the Waste Encapsulation and Storage Facility for processing cesium and strontium. Liquid effluents and waste go to several cribs with the 216-B designation and to 216-A-25 and 216-B-3 Ponds via both closed and open ditches. Solid wastes were sent to the 218-E Burial Grounds.

\subsection{PLANT - STRONTIUN SEMIWORKS (HOT SEMIWORKS)}

The C Plant commenced in 1952, operating until 1956. It was the pilot plant for the REDOX and PUREX processes. It was out of service for cleanup and modification until it started up again in 1960 and operated until 1967. Liquid effluents and wastes went to several cribs with the 216-C designation as well as the BC Cribs Area west of 200 East Area. Solid wastes were sent to the 218-E Burial Grounds.

\subsection{GROUT FACILITY}

The Grout Facility combined low-level liquid waste with a cement mixture that was pumped into disposal vaults. The Grout Facility commenced in 1986, became inactive during 1991, and closed operations in 1993. 

WHC-MR-0418, REV 0

\subsection{WEST AREA PROCESSING FACILITIES}

\subsection{S PLANT - REDOX AND 222-S LABORATORY COMPLEX}

The S Plant (REDOX) was the world's first nuclear solvent extraction plant and used the reduction/oxidation process. It commenced in 1952 and operated through 1967. Wastes and effluents were sent to several ponds via ditches and also to cribs identified with the 216-S designation. Solid wastes were sent to the 218-W Burial Grounds. Burial Ground 218-W-5 is of more recent construction and has probably not contributed to biotic uptake or transport of radionuclides.

The 222-S laboratory complex is located in the southeast corner of the 200 West Area. The facility is composed of the main laboratory complex and a number of ancillary buildings and structures. Liquid effluents and wastes were sent to the 216-S-25 Crib and cooling water to the 216-S-10 Ditch.

\subsection{2-S EVAPORATOR}

The 242-S Evaporator received liquid effluents to separate into streams to go either to the 216-U-14 Ditch and then into the 216-U-10 Pond or into the $S$ Tank Farms. Operations at this evaporator have been discontinued.

\subsection{T PLANT}

The T Plant was originally a fuel separation facility using the bismuth phosphate process. The facility is now used to decontaminate and repair equipment. This facility is currently active. The functions or processes associated with these facilities result in the use, storage, management, and disposal of radioactive and hazardous materials. Wastes and effluents from $T$ Plant were discharged to several cribs identified with the 216-T designation and the 216-T-1 Pond via two ditches. Solid wastes were sent to the 218-W Burial Grounds. The 216-T-1 Ditch is still active and receives intermittent waste from the head end of $T$ Plant.

\subsection{U PLANT AND $\mathrm{UO}_{3}$ - URANIUM OXIDE PLANT}

The U Plant commenced in 1952 for uranium recovery. It operated until 1957. The $\mathrm{UO}_{3}$ plant commenced in 1956 and operated unti1 1973. It operated again from 1984 until May 1989. Before going into the standby mode, $\mathrm{VO}_{3}$ converted uranyl nitrate hexahydrate (UNH) solution into uranium trioxide $\left(\mathrm{UO}_{3}\right)$ powder, which was then shipped off site for further processing. The $\mathrm{UO}_{3}$ Plant was on standby during 1990, but was used to complete processing of stored uranyl nitrate and then decommissioned. Liquid wastes and effluents from $U$ and $\mathrm{UO}_{3} \mathrm{Plants}$ were disposed to several cribs identified with the 216-U- designation. Low-level liquids went to the 216-U-10 Pond via the 216-U-14 Ditch. Solid wastes were sent to the 218-W Burial Grounds. 
WHC-MR-0418, REV 0

\subsection{Z PLANT - PLUTONIUM FINISHING PLANT}

The Z Plant commenced in 1949 and the complex, including the Plutonium Finishing Plant (PFP), operated intermittently until 1993 when the last run of material was processed. The PFP was used to process and prepare plutonium products. Liquid effluents and wastes were disposed to several cribs with the 216-Z- designation and to the 216-U-10 Pond via several 216-Z Ditches. Solid wastes were sent to the 218-W Burial Grounds.

\subsection{SOLID MASTE COMPACTOR FACILITY}

The Sol id Waste Compactor Facility, Building 213-W, is located in the 200 West Area of the Hanford Site. Building 213-W is adjacent to the 272-WA, Operations Support Building, at the 218-W-5 Burial Grounds at the west end of the 200 West Area. Systems ancillary to the 213-W Building are also included.

The primary function or process associated with the Solid Waste Compactor Facility is compacting and packaging dry, low-level radioactive wastes for disposal. The facility is currently in active operation.

\subsection{4-W PROTECTIVE EQUIPMENT DECONTAMINATION FACILITY (PEDF)}

The PEDF was located in the 200 West Area of the Hanford Site. The original laundry building was a wood and concrete structure that was constructed in 1952. It was expanded throughout its history using prefabricated metal buildings and mobile offices. Liquid effluents were originally disposed into the 216-U-14 Ditch and later into a crib. The PEDF has been shut down and dismantled.

\subsection{CENTRAL MASTE COMPLEX}

The Central Waste Complex (CWC) is a group of structures located on the west side of the 200 West Area exclusion zone on the Hanford Site. The primary function or process associated with the CWC Facility is the receipt and storage of radioactive and mixed wastes (MW) and includes the Pu/polychlorinated biphenyl (PCB) Storage Facility, the Low Flashpoint MW Storage Modules, the Mixed Waste Storage Facilities, the Mixed Waste Storage Pad, and the Waste Receiving and Storage Pad. The functions or processes associated with these facilities results in the storage and management of radioactive and hazardous materials. 
WHC-MR-0418, REV 0

\subsection{WASTE TREATMENT AND MANAGEMENT FACILITIES}

\subsection{TANK FARMS}

Liquid waste from chemical processing operations containing high concentrations of radionuclides is stored on an interim bas is in underground tanks. The Hanford Site tank farms contain 177 tanks (149 single-shell tanks [SST]) and 28 double-shel1 tanks (DST) with capacities ranging from 50,000 to $1,000,000$ gallons. Since 1967, new liquid waste has been stored in DSTs. The SSTs are no longer receiving waste. The wastes are planned to be disposed and the SSTs are to be decommissioned.

The tank farms, as part of the 200 Areas facilities, are discussed with emphasis placed on the DSTs and the related processes for those tank farms.

The general locations for all of the tank farms are in the 200 East and 200 West Areas. Both DSTs and SSTs are present. Tank farms in the 200 East Area include the $A, A X, B, B X, B Y, C$ (SSTs), AN, AZ, AY, AP, and AW (DSTs). Those in the 200 West Area are the S, SX, T, TX, TY, U (SSTS), and the SY (DST) Tank Farms.

Hanford tank farm facilities include the transfer routes, diversion boxes, storage vaults, double-contained receiver tanks (DCRT), and evaporators within the overall system.

A system of underground pipes is used to transfer wastes from the 200 East Area waste generators to the DSTs, between the DSTs, and from the DSTs to treatment and storage units in the 200 East and 200 West Areas.

\subsection{LOW-LEVEL BURIAL GROUNDS}

The low-level, radioactive, solid waste burial grounds are located in both the 200 Areas of the Hanford Site. The 200 West Burial Grounds include $218-W-1,218-W-1 A, 218-W-2,218-W-2 A, 218-W-3,218-W-3 A, 218-W-3 A E, 218-W-4$, $218-W-4 A, 218-W-4 B, 218-W-4 C, 218-W-5,218-W-6,218-W-5$, and 218-W-6. The 200 East Area Burial Grounds include 218-E-1, 218-E-2, 218-E-2A, 218-E-4, 218-E-5, 218-E-5A, 218-E-8, 218-E-9, 218-E-10 (Expansion), 218-E10, 218-E-12A, and 218-E12B.

Burial Ground 218-W-3A began receiving waste in 1970 and consists of 61 trenches. Waste stored or disposed of included mixed, transuranic, low-level, and retrievable waste. Examples of waste placed in these burial grounds included ion-exchange resins and industrial waste (failed equipment, tanks, pumps, ovens, agitators, heaters, hoods, jumpers, vehicles, and accessories). This burial ground also stored spent fuel.

Burial Ground 218-W-3AE began receiving waste in 1981 and it consisted of 31 trenches. Waste in this burial ground included both low-level and mixed waste. Examples of waste placed in this burial ground included rags, paper, rubber gloves, disposable supplies, broken tools, and industrial waste. 
Burial Ground 218-W-4B began receiving waste in 1968 and consisted of 13 trenches and 12 caissons. The trenches contained mixed and retrievable transuranic waste and were filled before 1980. Caisson Alpha 4 is believed to contain mixed waste.

Burial Ground 218-W-4C began receiving waste in 1978 and consisted of 69 trenches. Waste in this facility included transuranic, mixed, and low-level waste. Examples of waste placed in trenches include contaminated soil, decommissioned pumps, pressure vessels, hardware, and stored spent fuel. Some of the trenches were designed for retrievable storage.

Burial Ground 218-W-5 began receiving waste in 1986. The facility originally consisted of 35 trenches, with plans for eventual expansion. The trenches contained low-level mixed waste that included lead bricks and shielding. Low-level waste was also placed in this 1 andfill.

Burial Ground $218-W-6$ has not received any waste to date. When developed, this burial ground will consist of 35 trenches.

Burial Ground 218-E-10 began receiving waste in 1960 and consisted of 18 trenches. Waste at this site was received from the PUREX PIant, B PIant, and $N$-Reactor, and included low-level and low-level mixed waste such as drag-off waste, failed equipment, and industrial waste.

Burial Ground 218-E-12B began receiving waste in 1967 and consists of 94 trenches. Areas were set aside for future expansion of this burial ground. Waste contained in this burial ground included mixed waste, low-levei, and transuranic waste. 


\subsection{RADIOACTIVELY CONTAMINATED AREA}

A11 radioactive waste disposal sites, such as the burial grounds, cribs, trenches, retention basins, and unplanned release sites, are routinely surveyed. The surveys are performed at least annually, but may be done quarterly or semiannually. The number of surface contaminated acres varies. The number is not constant because there is a continuing effort to clean, interim stabilize, or remedy known contaminated areas while new areas of contamination continue to be identified. Newly identified contamination may be from contamination migration (wind blown or biological intrusion) or changing radiological criteria. It is estimated that $80 \%$ of the surface contamination is less than $1 \mathrm{mrem} / \mathrm{h}$.

Radioactively contaminated areas are posted as "Surface Contamination Area," "Radiologically Controlled Area," or "Underground Radioactive Material." Radiologically controlled areas are large posted areas with a high potential for encountering spotty or speck contamination. Surface contamination areas have more widespread contamination. "Underground radioactive material" signs mark cribs, burial grounds, and covered trenches and ponds. If an area has surface as well as underground contamination, such as a surface contaminated crib, it would be posted with both signs.

Table 2. Radioactive Contaminated Acres at the Hanford Site (1993).

\begin{tabular}{|c|c|c|}
\hline $\begin{array}{l}\text { Hanford Site } \\
\text { (by area) }\end{array}$ & $\begin{array}{l}\text { Surface contamination } \\
\text { estimated (acres) }\end{array}$ & $\begin{array}{l}\text { Underground rad } \\
\text { material }{ }^{\text {(acres) }}\end{array}$ \\
\hline 100 Areas & 160 & 460 \\
\hline 200 Areas & 324 & 374 \\
\hline 600 Area & 125 & 230 \\
\hline $\begin{array}{c}\text { BC cribs controlled } \\
\text { areas }\end{array}$ & $2,500(\mathrm{RCA})^{c}$ & 30 \\
\hline 300 Area & 45 & 30 \\
\hline Totals & 3,154 & 1,124 \\
\hline
\end{tabular}

"Includes areas posted as "Surface Contamination Areas" or as "Radiologically Controlled Areas" and areas that have both underground and surface contamination.

bincludes areas with only underground contamination. Does not include areas that have surface as well as underground radioactive material.

'Radiologically Controlled Area.

\subsection{CURRENT KNOWN TERRESTRIAL BIOTA CONTAMINATION}

The waste in the 200 Areas is mainly buried in, or have been disposed to, distinct cribs, trenches, or other such facilities. The highest concentrations of contaminants have been demonstrated to remain in and around these waste sites. Thus, the contamination might also be in nearby vegetation that have roots extending into the wastes. However, many waste sites are 
sprayed with herbicide each year, to minimize this pathway. Sites that have been disturbed in the past by waste disposal operations were predominately covered by cheatgrass, Russian thistle, and tumblemustard (when vegetation was present at all).

Schmidt et al. (1992) report the results of the 200 Areas vegetation sampling. Cesium-137 concentrations averaged 0.4 (all results reported in $\mathrm{pCi} / \mathrm{g}$ ) with a maximum of 3.0 ; strontium-90 averaged 0.063 , with a maximum of 4.1 ; and plutonium-239 and -240 averaged 0.004 , with a maximum of 0.05 . See Schmidt et a1. (1992) for these and other vegetation sampling results and locations.

Schmidt et al. (1992) report 32 radioactively contaminated wildlife and nests in the 200 Areas for 1991: one bird feces, two barn swallows, six barn swallow nests, one raven, one cottontail, and 21 house mice (see Schmidt et a). for results). Woodruff et al. (1992) report a maximum 1991 concentration of Cesium-137 in deer from the 200 Areas of $0.007 \mathrm{pCi} / \mathrm{g}$.

\subsection{CURRENT KNOWN RIPARIAN AREA AND BIOTA CONTANINATION}

The 200 Areas had several ponds and ditches that were used to dispose of wastewater (including contaminated effluents). Most of these have not been used in many years and have been filled in or covered. Others, however, still receive water and support riparian vegetation and wildlife; these include the following:

1. The 216-T-4 Ditch (200 West) Area received liquid waste in the past. The associated receiving ponds are dry, with bunchgrass and cheatgrass cover.

2. The 216-U-14 Ditch (200 West Area) received mostly 1aundry wastewater. DOE/RL (1992a) estimates the total release to be 225,000 of corrosive liquid and $100 \mathrm{lb}$ of uranium.

3. The 216-S-10D Ditch (south of 200 West Area) has been interim stabilized; the area is marked with "Underground Radioactive Contamination" signs.

4. The 200 E Powerhouse Ditch (200 East Area). There is no evidence of contamination ever being discharged to this ditch.

5. The B Pond system (east of 200 East Area). A RCRA study (Kramer $1991)$ in this area showed up to $718 \mathrm{pCj} / \mathrm{g}$ beta $(n=63)$ and 18.4 $\mathrm{pCi} / \mathrm{g}$ alpha $(n=63)$ in sediment from $216-\mathrm{B}-3 \mathrm{C}$ Pond. The maximum detected strontium-90 result for the system of ponds was 4.03 $\mathrm{pCi} / \mathrm{g}(\mathrm{n}=12)$, the maximum cesium-137 was $290 \mathrm{pCi} / \mathrm{g}(\mathrm{n}=12)$, both from 216-B-3 Pond. For cadmium, lead, and mercury, several samples exceeded the upper limits of the common ranges for soils and the background levels of $B$ Pond. However, none of the reported levels were close to the levels demonstrating characteristic toxicity. The results for chlorinated herbicides, chloropesticides, phosphorous pesticides, polychlorinated biphenyls, semivolatiles, and volatile organics showed that none 
were constituents of concern in the B Pond sediments. This pond is being decommissioned and interim stabilized.

6. The 2101-M Pond (200 East Area). This pond has received extensive sampling for a recent closure plan (DOE/RL 1991). While some analytes were above background levels and thus carried forward in the inventory of constituents to be considered during closure, the closure plan states that "Assuming that dangerous waste and/or dangerous waste constituents did enter the 2101-M Pond, the waste is present in concentrations that do not pose a present or potential threat to human health or the environment."

7. West Lake, north of the 200 East Area, is a natural pond that results from a rising water table and may be influenced by disposal of waste liquids to the ground. The water table has measurable radionuclide concentrations. Vegetation and coot eggshells from the lake have been reported to contain low, but detectable levels of radionuclides, such as uranium, strontium-90, and cesium-137 (Poston et al. 1991).

other ditches and ponds have been backfilled, and now have a cover of cobble or dryland grasses and tumbleweeds.

Waterfowl using these ponds had been identified as probably having a large potential for contaminant transport to man (Rogers and Rickard 1977). They are also important in nonhuman food webs (for example, waterfowl are prey for eagles, and their nests are subject to predation by skunks and snakes). Consequentiy, waterfowl from these ponds have been routinely monitored as part of the SESP conducted by PNL. Recent studies (Bisping and Woodruff 1992) showed the levels of radionuclides in $B$ Pond duck breast tissue $(n=10$, at least 6 of which were mallard) averaged $0.871 \mathrm{pCi} / \mathrm{g}$ of cesium-137, with a maximum of $1.85 \mathrm{pCi} / \mathrm{g}$. These results, from samples collected in 1990, are consistent with results from 1987, 1988, and 1989 samples, and are less than those B Pond duck sample results for 1986 (Woodruff et al. 1991). Rogers and Rickard (1977) also reported the results of waterfowl productivity studies with coots on Gable Mountain pond (with low-level contamination) versus two offsite ponds near 0the110, Washington, and reported no noticeable effects on species productivity. Poston et al. (1991) reported elevated levels of strontium-90 in coot eggshells from West Lake, in concentrations from 4.7 to $5.6 \mathrm{pCi} / \mathrm{g}$.

\subsection{CONTAMINATION SUMMARY}

Rogers and Rickard (1977) presented a thorough overview of the ecology of the 200 Areas plateau, especially as it relates to contaminant migration through the biota. They listed several factors that "severely minimize" the potential risk to humans from contamination through this food web:

1. The aridity of the region naturally results in a low biological productivity. Therefore, there are relatively few native organisms normally consumed by mankind. 
2. Irrigated crop lands and domestic livestock are both major pathways to man, absent from waste management environs- a major pathway to man.

3. The substantial protected areas surrounding the waste management facilities serve to minimize the possibility for transport of hazardous materials off the Hanford Site.

4. Native organisms known to possibly represent a pathway to man are routinely sampled for radionuclide analysis as part of the radiological monitoring program.

However, the Comprehensive Environmental Response Compensation and Liability Act (CERCLA) requires a risk assessment for not only humans, but also for the environment. Thus, the importance of individual components of the food web must also be considered in relation to each other to determine ecological risk. 


\subsection{CONTAMINANTS OF CONCERN}

Cesium-137, strontium-90, plutonium-239 and -240 , and uranium have been recognized as occurring in measurable levels in the near-facility biota, are radionuclides of relatively long half-lives, and are the radionuclides reported in this document. However, DOE/RL (1992a) lists other contaminants of concern, such as heavy metals, gross alpha, gross beta, and technetium-99. The current recommended analytes for characterization samples are as follows: gross alpha, gross beta, gamma spectroscopy (which includes cesium-137 and cobalt-60), total uranium, plutonium-239 and -240 , technetium-99, and metals, including mercury and lead. 
WHC-MR-0418, REV 0

This page intentionally left blank. 


\subsection{SUMNARY}

This document summarizes and reports the results of a literature search of 85 radiological monitoring records of environmental parameters, including biota at the 200 East Area and the 200 West Area of the Hanford Site since 1965. These records of environmental monitoring were published annually and are the source of the majority of the data in this report. Additional sources of data have included records of specific facilities such as site characterization documents and preoperational environmental surveys. Records before 1965 were still being researched and therefore not included in this document. The intent of compiling these data into a single source was to identify biotic uptake of radionuclides at specific waste sites within each operable unit to help determine priorities of cleanup activities.

The references to species in the referenced reports varied from extremely general (e.g., mouse, bird, rabbit, vegetation) to specific (e.g., deer mouse, brewer's blackbird, black-tailed jackrabbit, Russian thistle). The references to location also varied from extremely general (e.g., 200 Areas) to specific (e.g., $244 \mathrm{~A}$ Lift Station). Even the radioactivity analyses results varied, sometimes reporting only general information (e.g., 7,000 counts per minute of total radioactivity as determined from a field survey instrument) were reported and sometimes specific (e.g., 3,000 pCi/g of strontium-90) analyses data were reported.

For the purposes of this document, a sample was of interest if a GeigerMueller counter equipped with a pancake probe indicated beta/gamma emitting radioactivity above 200 counts per minute $(\mathrm{cpm})$, or if laboratory radioanalyses indicated a radionuclide concentration equaled or exceeded 10 $\mathrm{pCi} / \mathrm{g}$. About 4,500 individual cases of monitoring for radionuclide uptake or transport in biota in the 200 Areas environs were included in the documents reviewed. About 1,900 (i.e., 42\%) of these biota had radionuclide concentrations in excess of $10 \mathrm{pCi} / \mathrm{g}$. These radionuclide transport or uptake cases were distributed among 45 species of animals (mostly small mammals and feces) and 30 species of vegetation. The animals species most commonly associated with radioactive contamination were the house mouse and the deer mouse and of vegetation species, the Russian thistle.

Comparison of the data in the Appendix showed that of about 2,400 biotic samples collected during routine monitoring from near the operations areas, only about 120 (i.e., about 5\%) exceeded $1.0 \mathrm{E}+01 \mathrm{pCi} / \mathrm{g}$ concentration. Comparatively, of about 2,100 biotic samples collected during special investigations at known or suspected contaminated sites, about 1,800 (i.e., about $86 \%$ ) exceeded concentrations of $1.0 \mathrm{E}+01 \mathrm{pCi} / \mathrm{g}$, indicating that radionuclide contamination has remained relatively localized even though it has spread beyond intended waste site boundaries. It should be noted that even the routine monitoring is targeted to detect potential radioactive contamination at nuclear facilities and waste sites, while the special investigative samples are usually targeted at known incidents of biotic uptake and transport; both results are therefore biased towards detection of radioactivity. These data should not be used to make inferences about the overall condition of biotic uptake and transport of radionuclides over the entire Hanford Site. 
Radionuclide concentrations in vegetation were highest in Russian thistle (3.2E+06 pCi/g of strontium-90) in 1981 at the 216-BC Cribs just south of the 200 East Area. The $\mathrm{BC}$ Cribs area has since been interim stabilized. Other high concentrations were found in rabbitbrush (up to $8.0 \mathrm{E}+05 \mathrm{pCi} / \mathrm{g}$ of strontium-90) growing on the 216-A-24 Crib in 1981; this Crib has also since been interim stabilized. For comparison purposes, the WHC strontium-90 standard (WHC-CM-7-5, Environmental Compliance), for releasing an area from radiological controls in the 200 Areas is $2.8 E+03 \mathrm{pCi} / \mathrm{g}$. Since 1965 , there have been about 1,100 cases of uptake by vegetation in the 200 Areas resulting in concentrations greater than $1.0 \mathrm{E}+01 \mathrm{pCi} / \mathrm{g}$.

The highest radionuclide concentration in animals $(6.6 \mathrm{E}+10 \mathrm{pCi} / \mathrm{g}$ of cesium-137) was in a house mouse from 241-BX Tank Farm in 1991. The Tank Farm surface soil was being stabilized in 1994. Other notable concentrations of radionuclides in animals were $1.8 \mathrm{E}+09 \mathrm{pCj} / \mathrm{g}$ of strontium-90 in coyote feces found west of 241-C Tank Farm in $1971 ; 2.5 \mathrm{E}+09 \mathrm{pCi} / \mathrm{g}$ of strontium-90 in a house mouse at 244-A Lift Station in $1991 ; 4.0 \mathrm{E}+08 \mathrm{pCi} / \mathrm{g}$ of strontium-90 in mouse feces at $218-E-12 A$ Burial Ground in $1985 ; 6.8 \mathrm{E}+08 \mathrm{pCi} / \mathrm{g}$ of strontium-90 found in rabbit feces near 202-S (REDOX); $1.5 E+08 \mathrm{pCi} / \mathrm{g}$ of strontium-90 in a house mouse at 221-T in 1992; $7.2 \mathrm{E}+07 \mathrm{pCi} / \mathrm{g}$ of strontium-90 in mice at the Cross-country Transfer Line Vent Station in 1982; and $2.1 \mathrm{E}+07 \mathrm{pCi} / \mathrm{g}$ of plutonium-239 and -240 in coyote feces found east of 221-T in 1978. Since 1965, there have been about 830 cases of radionuclide uptake by animals in the 200 Areas resulting in concentrations greater than $1.0 \mathrm{E}+01 \mathrm{pCi} / \mathrm{g}$. Of the 50 highest concentrations of radionuclides found in biota near the 200 Areas, 42 have occurred in animals, and the 10 highest concentrations have all been in animals. The radionuclides among the 50 highest concentrations have been strontium-90 (20), cesium-137 (29), and plutonium-239 and -240 (1); however, strontium-90 accounted for eight of the 10 highest concentrations.

The largest numbers and levels of radionuclide uptake or transport have occurred at 202-S (REDOX) Facility, 202-C (Hot-semi Works) Facility, 216-A-8 Crib, 216-A-24 Crib, 216-A-40 Basin, 216-B-3 Ditches, 216-BC Cribs, 216-S Ponds, 216-U-8 Crib and Pipeline, 216-Z Ditches, 241-B Tank Farm, 241-BX/BY Tank Farm, 241-C Tank Farm, and 244-A Lift Station. Partial or complete decommissioning and interim stabilization have since occurred at most of these facilities and sites. Sites where biotic intrusion and transport that still need to be stabilized include the tank farms, the remaining ditches, and those parts of facilities, such as REDOX and PUREX, which have not been stabilized.

In addition to the monitoring programs in the 200 Areas, there are aggressive vegetation and animal control programs. The vegetation control program uses revegetation and herbicide application to stabilize around facilities and on waste sites. The animal control program is both a response to pest complaints and control of animal populations that could get into radioactive waste. One function of the OEMP is to indicate when waste containment, vegetation control, or animal control systems have or are in the process of failing. One of the ways failure occurs is through biotic intrusion, such as root penetration or burrowing penetration of barriers. When such problems are identified, steps are taken to interim stabilize these sites. Interim stabilization has also been done when a facility or waste site is taken out of operation. Typically, the sampling data have shown a significant decrease in biotic uptake of radionuclides at these remediated sites. Sites where decreases in biotic uptake can be attributed to interim stabilization include the 216-A-24 Crib, 216-A-25 Pond, 216-B-1, -2, and -3 
Ditches, 201-C Hot Semiworks, 216-S-16, -17, and -19 Ponds, and the 216-U-10 Pond. Other locations that have had considerable biotic uptake include the Cross-country Transfer Line, 216-A-40 Basin, 244-A Lift Station, and 216-B-3 Pond (fairly common but also very low level), all of which are undergoing interim stabilization in 1994. The surfaces of the tank farms and those outdoor contaminated areas around the facilities, such as REDOX and PUREX, are also being surface stabilized to prevent migration of contamination.

Because of the variation in reporting results, it was often not possible to establish relationships between potential for contamination and radionuclide concentrations observed in biota beyond identifying contaminated areas of known access to biota and using that information to help prioritize cleanup actions. The data do seem to indicate an overall downward trend in both numbers of cases of radionuclide uptake by biota and levels of uptake. This reduction may be a result of a decrease in radionuclide half-lives over time, cessation of operation activities, or improved barriers to biotic intrusion. Most likely a combination of these factors was responsible for the observed apparent effect.

The data in the single Appendix are sorted by waste site and are presented on a computer disk as a Wordperfect file. 
WHC-MR-0418, REV 0

This page intentionally left blank. 


\subsection{REFERENCES}

* 47

Herde, K. E., 1947, Biological Monitoring of the Laboratory Areas by Analyses of Rodents and Other Forms of Animals, AECD-288, Hanford Atomic Products Operation, General Electric Company, Richland, Washington.

* 52

Hanson, W. C., R. L. Browning, and W. H. Brayman, 1952, Waterfow7 Contamination Observed at REDOX Swamp During December, 1952, HW-27104, Hanford Atomic Products Operation, General Electric Company, Richland, Washington.

$66 a$

Foster, R. F., D. Moore, and T. H. Essig, 1966, Evaluation of Radiological Conditions in the Vicinity of Hanford for CY 1965 Appendices, BNWL-316 APP.

* 66b

Essig, T. H. and R. B. Hal1, 1966, Environmental Status of the Hanford Project - 1965 Annual Summary, BNWL-CC-913.

67

Essig, T. H. and R. B. Ha11, 1967, Environmental Status of the Hanford Reservation for December 1966 (Annual Summary), BNWL-CC-637-12.

68 Woolridge, C. B., 1968, Environmental Status of the Hanford Reservation for November-December 1967 (Annual Summary), BNWL-CC-1197-6.

* 69

Woolridge, C. B., 1969, Evaluation of Radiological Conditions in the Vicinity of Hanford for CY 1967, BNWL-983.

70

Corley, J. P. and C. B. Wilson, 1970, Evaluation of Radiological

Conditions in the Vicinity of Hanford for 1969 - Appendices, BNWL-1505 APP.

$72 a$

Bramson, P. E. and J. P. Corley, 1972, Environmental Status of the Hanford Reservation for 1971, BNWL-B-228.

* $72 b$

Bramson, P. E. and J. P. Corley, 1972, Environmental Surveillance at Hanford for 1971, BNWL-1683.

$73 a$

Bramson, P. E., J. P. Corley, and W. L. Nees, 1973, Environmental Status of the Hanford Reservation for $\mathrm{CY}$ 1972, BNWL-B-278. 
* 73b

Corley, J. P., 1973, Environmental Surveillance at Hanford for CY 1970, BNWL-1669.

* $73 \mathrm{c}$

Bramson, P. E. and J. P. Corley, 1973, Environmental Surveillance at Hanford for CY 1973, BNWL-1727.

* 73d

Corley, J. P., 1973, Environmental Surveillance at Hanford for Cr 1970 Data, BNWL-1669 ADD.

* $74 a$

Nees, W. L. and J. P. Corley, 1974, Environmental Surveillance at Hanford for $\mathrm{Cr} 1973$, BNWL-1811.

* 74b

Rickard, W. H., J. D. Hedlund, and R. G. Schreckhise, 1974, Mammals of the Hanford Reservation in Relation to Management of Radioactive Waste, BNWL-1877.

* 75a

Fix, J. J., 1975, Environmental Surveillance at Hanford for $\mathrm{Cr}$ 1974, BNWL-1910.

$75 b$

Nees, W. L. and J. P. Corley, 1975, Environmental Status of the Hanford Reservation for $\mathrm{Cr} 1973$, BNWL-B-336.

$75 c$

Fix, J. J., 1975, Environmental Status of the Hanford Reservation for $\mathrm{Cr} 1974$, BNWL-B-429.

$76 a$

Speer, D. R., J. J. Fix, and P. J. Blumer, 1976, Environmental

Surveill ance at Hanford for $\mathrm{Cr} 1975$, BNWL-1979.

$77 a$

Fix, J. J. and P. J. Blumer, 1977, Radiochemical Analyses of Game Birds Collected from the Hanford Environs 1971-1975, BNWL-2089.

$77 b$

Fix, J. J., S. C. Leete, and P. E. Bramson, 1977, Radionuclide Concentrations in Selected Foodstuffs and Animals from the Hanford Environs, 1971-1975, PNL-2383.

77c

Panesko, J. V., E. H. Carbaugh, D. J. Carrel1, R. L. Dirkes, R. L. Laughman, H. L. Maxfield, and R. E. Wheeler, 1977, Environmental Protection Annual Report for CY 1976, ARH-LD-154.

77d

Rogers, L. E. and W. H. Rickard, 1977, Ecology of the 200 Areas Plateau Waste Management Environs: A Status Report, PNL-2253. 
WHC-MR-0418, REV 0

$78 a$

Houston, J. R. and P. J. Blumer, 1978, Environmental Surveillance at Hanford for CY 1977, PNL-2614.

$78 b$

Houston, J. R. and P. J. Blumer, 1978, Environmental Status of the Hanford Site for CY 1977, PNL-2677.

$78 c$

Panesko, J. V., R. L. Dirkes, K. Kover, and R. E. Wheeler, 1978, Rockwell Hanford Operations Environmental Protection Annual Report for cr 1977, RHO-LD-78-75.

$78 d$

Dabrowski, T. E., 1978, Radionuclide Concentrations in Ducks from $N$ Trench, June 29, 1978, Letter.

$79 a$

Cadwe11, R. E., R. G. Schreckhise, and R. E. Fitzner, 1979, Cesium-137 in Coots on Hanford Waste Ponds: Contribution to Population Dose and offsite Transport Estimates, PNL-SA-7167.

$79 b$

KTepper, E. L., L. E. Rogers, J. D. Hedlund, and R. G. Schreckhise, 1979, Radioactivity Associated with Biota and Sojls of the 216-A-24 Crib, PNL-1948.

$79 c$

Mitchel1, R. M. and D. S. Landeen, 1980, Biological Evaluation and Impact Assessment for the Proposed W-5 Burial Ground, RHO-CD-968.

79d

Houston, J. R. and P. J. Blumer, 1979, Environmental Surveillance at Hanford for $\mathrm{CY}$ 1978, PNL-2932.

$79 \mathrm{e}$

Bih1, D. E., G. F. Boothe, and R. L. Dirkes, 1979, Environmental Protection Annual Report for CY 1978, RHO-LD-79-75.

$79 f$

Blumer, P.J., 1979, Environmental Status of the Hanford Site for Cr 1978, PNL-2933.

$79 \mathrm{~g}$

Gano, K. A., 1979, Analysis of Small Mammal Populations Inhabiting the Environs of a Low-Level Radioactive Waste Pond, PNL-2479.

$80 a$

Wheeler, R. E. and A. W. Law, 1980, Rockwell Hanford Operations

Environmental Surveillance Report for CY 1979, RHO-LD-132.

$\star 80 \mathrm{~b}$

Frostenston, J. C., 1980, Rodent Control and Contamination Transport in the 200 Areas, RHO-CD-867. 
$80 \mathrm{c}$

Houston, J. R. and P. J. Blumer, 1980, Environmental Surveillance at Hanford for CY 1979, PNL-3283.

$81 a$

Wheeler, R. E., A. W. Conklin, R. E. Elder, W. L. Osborne, and M. J. Graham, 1981, Environmental Surveillance Annual Report for $\mathrm{Cr} 1980$, RHO-LD-163.

$81 b$

Sula, M. J. and P. J. Blumer, 1981, Environmental Surveillance at Hanford for CY 1980, PNL-3728.

$81 c$

Price, K. R., L. L. Cadwe11, R. G. Schreckhise, and F. P. Brauer, 1981, Iodine-129 in Forage and Deer on the Hanford Site and Other Pacific Northwest Locations, PNL-3357.

$82 a$

Sula, M. J., P. J. Blumer, and R. L. Dirkes, 1982, Environmental Status of the Hanford Site for CY 1980, PNL-3729.

$82 b$

SuTa, M. J., W. D. McCormack, R. L. Dirkes, K. R. Price, and P. A. Eddy, 1982, Environmental Surveillance at Hanford for CY 1981, PNL-4211.

$82 c$

Sula, M. J., P. J. Blumer, and R. L. Dirkes, 1982, Environmental Status of the Hanford Site for CY 1981, PNL-4212.

82d

Conklin, A. W., R. E. Elder, W. L. Osborne, and J. M. Pisarcik, 1982, Rockwell Hanford Operations Environmental Surveillance Annual Report for CY 1981, RHO-HS-SR-82-4P.

$82 \mathrm{e}$

Conklin, A. W., R. E. Elder, W. L. Osborne, and J. M. Pasarcik, 1982, Rockwell Hanford Operations Environmental Surveillance Annual Report, RHO-HS-SR-82-13 P.

$82 f$

Sula, M. J., P. J. Blumer, R. L. Dirkes, and J. M. V. Carlile, 1983, Environmental Status of the Hanford Site for CY 1982, PNL-4658.

$82 \mathrm{~g}$

Landeen, D. S. and R. M. Mitche11, 1982, The Role of Burrowing Activities of the Great Basin Pocket Mouse in the Dispersal of Radionuclides on a Decommissioned Pond, RHO-HS-SA-1OP.

$83 a$

Sula, M. J., J. M. V. Carlile, and W. D. McCormack, 1983, Environmental Surveillance at Hanford for $\mathrm{Cr}$ 1982, PNL-4657. 
83b

Conkl in, A. W., R. E. Elder, V. G. Johnson, W. L. Osborne, and A. G. Law, 1984, Rockwell Hanford Operations Environmental Surveillance Annual Report for CY 1983, RHO-HS-SR-83-13 1 P.

* 83c

Boothe, G. F., 1983, Inspection of Semiworks Facilities as a Potential Source of Biological Transport, (internal letter 72740-83-EMC-026).

$84 a$

Price, K. R., J. M. V. Carlile, R. L. Dirkes, and M. S. Trevathan, 1984, Environmental Surveillance at Hanford for $\mathrm{Cr}$ 1983, PNL-5038.

$84 b$

Price, K. R., P. J. Blumer, J. M. V. Carlile, R. L. Dirkes, and M. S. Trevathan, 1984, Environmental Status of the Hanford Site for Cr 1983, PNL-5039.

$84 c$

Landeen, D. S., 1984, Preoperational Environmental Survey in Support of the Basalt Waste Isolation Program's Exploratory Shaft, in preparation.

84d

Johnson, A. R., 1984, Findings of Biological Investigations into Contaminated Ant Mounds, RHO-SD-SQA-EV-010.

* $84 \mathrm{e}$

Johnson, A. R., 1984, Year End Report of Animal Control in the 200 Areas for FY 1984, (internal letter 65634-176).

$84 f$

Eberhardt, L. E. and L. L. Cadwe11, 1984, Radionuclide Concentrations in Mule Deer with Reference to Waste-Management

Ponds on the Hanford Site, PNL-SA-11401.

$85 a$

Conklin, A. W., R. E. Elder, and A. R. Johnson, 1985, Rockwell Hanford Operations Environmental Surveillance Report for $\mathrm{CY} 1984$, RHO-HS-SR-84-13P.

$85 b$

Price, K. R., J. M. V. Carlile, R. L. Dirkes, R. E. Jaquish, M. S. Trevathan, and R. K. Woodruff, 1985, Environmental Monitoring at Hanford for 1984 , PNL-5407.

85d

Landeen, D. S., R. M. Mitchell, K. R. Price, M. J. Shula, M. S. Trevathan, and L. J. Maas, 1985, PUREX Preoperational Environmental Survey Report, RHO-RE-ST-45 P. 
$86 a$

Elder, R. E., A. W. Conklin, D. D. Brekke, G. W. Egert, and W. L. Osborne, 1986, Rockwell Hanford Operations Environmental Surveillance Report for CY 1985, RHO-HS-SR-85-13P.

* $86 b$

Jacques, I. D., 1986, UNC Environmental Surveillance Report for the 100 Areas FY 1985, UNI-3760, UNC Nuclear Industries, Rich7and, Washington.

86c

Price, K. R., 1986, Environmental Monitoring at Hanford for 1985 PNL-5817.

86d

Landeen, D. S. and R. M. Mitche11, 1986, "Radionuclide Uptake by

Trees at a Radwaste Pond in Washington State," in Journal of Health Physics, Vol. 50, No. 6, pp. 769-774.

* 87a Jacques, I. D., 1987, UNC Environmental Surveillance Report for the 100 Areas FY 1986, UNI-4065, UNC Nuclear Industries, Richland, Washington.

87b

Elder, R. E., G. W. Egert, A. R. Johnson, and W. L. Osborne, 1987, Rockwell Hanford Operations Environmental Surveillance Annual Report for CY 1986, RHO-HS-SR-86-13 P.

87c

Elder, R. E., G. W. Egert, A. R. Johnson, and W. L. Osborne, 1988, Westinghouse Hanford Company Environmental Surveillance Annual Report-200/600 Areas for CY 1987, WHC-EP-0145.

$88 a$

Jaquish, R. E. and P. J. Mitche11, 1988, Environmental Monitoring at Hanford for 1987, PNL-6464.

88b

Perkins, C. J., 1988, Westinghouse Hanford Company Environmental Surveillance Annual Report-100 Areas, CY 1987, WHC-EP-0601.

$88 \mathrm{c}$

Swanson, L.C., D. C. Weekes, S. P. Luttre11, R. M. Mitche11, D. S. Landeen, A. R. Johnson, and R. C. Roos, 1988, Grout Treatment Facility Environmental Baseline and Site Characterization Report, WHC-EP-0150.

$89 a$

Jaquish, R. E. and R. W. Bryce, 1989, Hanford Site Environmental Report for Calendar Year 1988, PNL-6825.

$89 \mathrm{~b}$

Elder, R. E., S. M. McKinney, and W. L. Osborne, 1989, Westinghouse Hanford Company Environmental Surveillance Annual Report--200/600 Areas CY 1988, WHC-EP-0145-1. 
WHC-MR-0418, REV 0

$89 c$

Jaquish, R. E. and R. W. Bryce, 1989, Hanford Site Environmental Report for Calendar Year 1989, PNL-7346.

90a

Schmidt, J. W., C. R. Huckfeldt, A. R. Johnson, and S. M. McKinney, 1990, Westinghouse Hanford Company Environmental Surveill ance Annual Report--200/600 Areas, WHC-EP-0145-2.

$91 \mathrm{a}$

Schmidt, J. W., A. R. Johnson, S. M. McKinney, C. J. Perkins, and C. R. Webb, 1992, Westinghouse Hanford Company Environmental Surveillance Annual Report for CY 1991, WHC-EP-0573.

91b

Bisping, L. E. and R. K. Woodruff, 1991, Hanford Site Environmental Data for CY 1991, PNL-8149.

$92 a$

Schmidt, J. W., C. R. Webb, A. R. Johnson, and S. M. McKinney, 1992 , Westinghouse Hanford Company Environmental Surveillance Annual

Report--200/600 Areas for CY 1990, WHC-EP-0145-4.

* $92 b$

Weiss, S. G. and R. M. Mitche11, 1992, A Synthesis of Ecological Data

from the 100 Areas of the Hanford Site, WHC-EP-0601.

* $92 \mathrm{C}$

WHC Notification Report, 1992, Contamination Discovered Outside of Controlled Area, WHC-TPIant-1992-0045, Westinghouse Hanford Company, Richland, Washington.

* 92d

WHC Notification Report, 1992, Contamination Discovered Outside of Controlled Area, WHC-TPI ant-1992-0037, Westinghouse Hanford Company, Richland, Washington.

* 92e

WHC Notification Report, 1992, Contaminated Bird Nest Found in a Nonradiologically Controlled Area, RL-WHC-PUREX-1992-0037, West inghouse Hanford Company, Richland, Washington.

* $92 f$

Schmidt, J. W., 1992, Hot Swallow's Nest, cc:Mail Message 5/13/92, 9:22 am.

* $92 \mathrm{~g}$

WHC Notification Report, 1992, Contamination Found in a Government Vehicle Glove Box, KEH-1992-0088, Westinghouse Hanford Company, Richland, Washington.

92h

Schmidt, J. W., A. R. Johnson, S. M. McKinney, and C. J. Perkins, 1993, Westinghouse Hanford Company Operational Environmental

Monitoring Annual Report for CY 1992, WHC-EP-0573-1. 
WHC-MR-0418, REV 0

93a

Bisping, L. E. and R. K. Woodruff, 1993, Hanford Site

Environmental Data for CY 1992, PNL-8683.

« V101. 
WHC-MR-0418, REV 0

APPENDIX

A-i 
The appendix is provided on an IBM compatible 3.5-in. disk in WordPerfect format. An ASCII file is available upon request.

The appendix is a single table of 10 columns arranged as follows: Year (year the sample was collected); Reference (year the analytical result was published and designated in the bibliography by the same reference number); Operable Unit (geographical areas designated for purposes of similarity of cleanup actions); Location (location the sample was collected); Group: Species (the term "group" designates whether the sample was vegetation, waterfow1, upland game bird, mammal, bird, reptile, or insect; the term "species" designates the specific kind of vegetation or animals identified in the published reference); Field Instrument Levels (external radioactivity, where recorded, as measured on one of several types of instruments used to detect gross radioactivity and recorded as counts per minute [Cpm] or millirads per hour [mrads/h]); Cs-137 (the radionuclide cesium-137); Sr-90 (the radionuclide strontium-90); Pu-239 (the radionuclides plutonium-239 and -240); and Uranium (total concentration of all uranium isotopes). All radionuclide (a)so referred to as radioisotope) concentrations are given in picocuries per gram $(\mathrm{pCi} / \mathrm{g})$; a measure of concentration, not dose.

These data are useful for determining the overall gross levels of radionuclide concentrations in the 200 Areas and helping establish priorities for cleanup at the various locations and not for determining dose or health effects. Because of variability of monitoring purposes and techniques, variability of radioactivity emitted by the various radionuclides, and variability of analytical methods (both over the years and at different laboratories), intercomparisons must be made with great caution.

The primary purpose of this compilation was to assist in establishing priorities for Hanford Site cleanup. The data were sorted by location to help establish priorities for Hanford Site cleanup; however, the data can be sorted by any category desired. 
WHC-MR-0418, REV 0

DISTRIBUTION

Number of copies

OFFSITE

U.S. Department of Energy-

Headquarters

R. W. Barber (2)

1

EG\&G Idaho, Inc.

P.0. Box 1625

Idaho Falls, Idaho 83415-4110

K. C. Wright

1 Golder Associates

4104 148th Ave. NE

Redmond, Washington 98052

Library

2

I.T. Corporation

1045 Jadwin

Richland, Washington 99352

J. Chiramonte

D. A. Myers

$1 \quad$ U.S. Dept of Interior

Fish and Wildlife Service

Columbia Nat'l Wildlife Refuge

P.0. Drawer $F$

Othello, Washington 99344

D. E. Goeke

1

U.S. Ecologr, Inc.

P.0. Box 638

Richland, Washington 99352

A. Palmer

2

U.S. Environmental Protection Agency, Region 10

712 Swift Boulevard, Suite 5

Richland, Washington 99352

L. E. Gadbois

B5-01

D. R. Sherwood

B5-01

Number of copies OFFSITE

Washington Public Power Supply System

P.0. Box 968

Richland, Washington 99352

T. Chrisler

MD-1020

Distr-1 
2

Washington State Department of Ecology

7601 W. Clearwater, Suite 102

Kennewick, Washington 99336

D. Tee1

4

Washington State Department of Health

Division of Radiation Protection

Airdustrial Cntr. Bldg. 5

P.0. Box 47827

Olympia, Washington 98504-0095

R. A. Danielson

MS-7827

J. L. Erickson (3)

MS-7827

2

U.S. Army Corps of Engineers

Walla Walla, Washington 99362

A. Foote

$A C-20$

W. C. Greenwald

$A C-20$

1

Westinghouse Electric Corporation WIPP

P.0. Box 2078

Carlsbad, New Mexico 88221

S. B. Jones

Number of copies

OFFSITE

Washington Department of Wildl ife

Lower River Road

Benton City, Washington 99320

L. Fitzner 
U.S. Department of Energy. Richland Operations Office

R. F. Brich

A5-55

E. B. Dagan

A5-15

P. F. Dunigan Jr

A5-15

J. K. Erickson

A5-19

B. L. Foley

A5-19

M. J. Furman

R3-80

E. D. Goller

A5-19

J. B. Hall

A5-55

J. M. Hennig

R3-80

R. D. Hildebrand

A5-55

R. G. Holt

R. A. Holten

A5-15

J. E. Mecca

A5-55

P. M. Pak

R. 0. Puthoff

R. K. Stewart

S. D. Stites

R3-81

M. L. Talbot

A5-19

A5-10

A5-19

A5-15

K. M. Thompson

A7 -75

D. C. Ward

A5-19

Public Reading Room (4)

A5-55

Al-65

1 Hanford Environmental Health Foundation

B2-75

B. B. Milburn

2 Bechtel Hanford Incorporated

S. R. Weil

H4-79 
WHC-MR-0418, REV 0

\section{Number of copies ONSITE 19}

\section{Pacific Northwest Laboratory}

E. J. Antonio

K6-61

L. L. Cadwell

K6-63

R. L. Dirkes

S. L. Friant

K6-61

K6-52

R. H. Gray

R. W. Hanf

R. E. Jaquish

B1-34

K6-61

B1-34

J. A. Hall

E. W. Lusty

G. W. Patton

K6-61

K6-79

K. L. Petersen

K6-61

T. M. Poston

K6-63

K6-61

K6-52

K3-54

K. Rhoads

M. R. Sackschewsky

K6-63

J. K. Soldat

H. T. Tilden

B. L. Tiller

R. K. Woodruff 
Number of copies ONSITE 190

Westinghouse Hanford Company

M. R. Adans

H6-01

M. D. Aichele

T4-04

D. Alison

R2-86

M. V. Berriochoa (10)

B3-30

J. F. Brown

R. J. Bottenus

R2-86

D. B. Bl umenkranz

N3-13

R. A. Carlson

S. W. Clark

P. J. Crane

J. D. Dederick

L. P. Diediker

J. J. Dorian

B. G. Erlandson

R. D. Fox

T. W. Ferns

K. R. Fecht

G. E. Fitzgibbon (2)

D. L. Flyckt

M. J. Galgoul

H6-01

H6-03

H6-01

T3-28

B2-16

T1-30

H6-30

H6-20

H6-07

A5-19

H6-06

H6-07

K. A. Gano

R. F. Giddings (3)

R3-45

H6-04

C. J. Geier

E. M. Greager

W. T. Gretsinger

$\mathrm{XO}-21$

N3-06

R2-36

H6-30

R2-86

M. L. Grygiel

P. R. Gunter

B1-58

R2-86

R. D. Gustavson

R1-51

S. J. Guzek

D. L. Halgren

M. J. Hall

D. G. Hamrick

H6-01

S6-70

T6-07

J. W. Handy

D. E. Hare

S6-15

H6-22

W. M. Hayward

S3-97

C. E. Heiden

T7-05

W. F. Heine

R. E. Heineman, Jr

H6-01

B3-63

G. C. Henckel

D. R. Herman

R3-12

H6-04

M. E. Hevland

S2-12

R3-12

M. C. Hughes

X5-55 
WHC-MR-0418, REV 0

Number of copies

ONSITE

Westinghouse Hanford Company (cont)

R. M. Irwin

T4-03

G. J. Jackson

H6-04

D. B. Jensen

A. R. Johnson (50)

H6-30

R. J. Julian

C. J. Kentp

C. D. Kramer

D. S. Landeen (2)

N. K. Lane

J. H. LaRue

M. J. Lauterbach

A. G. Law

G. J. LeBaron

C. L. Looney

J. G. Lucas

W. C. Mallory

B. M. Markes

R. P. Marsha11

D. J. McBride

R. G. McCain

A. K. McDowe11

S. M. McKinney

H6-30

S6-65

H4-14

H6-03

H4-14

H6-01

H6-21

H6-01

H6-06

56-19

T1-20

H6-01

T4-03

H6-30

T6-14

T5-54

H6-01

RI-51

M. A. Mihal ic

T1-30

R. M. Mitche11

M. R. Morton

K. J. Moss

W. L. Osborne

E. J. Papin

M. A. Payne

C. J. Perkins

R. D. Pierce

D. B. Powell, Jr

$\times 5-53$

H6-01

$\times 5-55$

$\times 0-21$

T7-05

H6-03

57-14

$\mathrm{X} 0-21$

T3-04

W. H. Price

T4-03

G. R. Priddy, Jr

N3-05

J. R. Prilucik

โ8-17

F. V. Roeck

T6-24

R. C. Roos

H6-01

C. A. Rowley

H6-01

J. W. Schmidt

H6-01

A. N. Shah

H6-30

D. L. Smith

H6-30

J. C. Sonnichsen

T7-05

J. A. Stegen

H4-14

H6-02 
Number of copies ONSITE

Westinghouse Hanford Company (cont)

J. A. Stegen

H6-02

R. R. Thompson

H6-32

M. A. Tredway

R3-54

T. B. Veneziano

H6-10

J. L. Waite

M. A. Wasemiller

R. L. Watts

B. F. Weaver

R. S. Weeks

D. L. Wegener

S. G. Weiss (20)

J. D. Williams

K. J. Wilson

T. M. Wintczak

C. D. Wittreich

B2-35

H6-04

L6-52

R3-45

H6-26

R1-62

H6-02

H6-28

H6-30

H6-27

J. G. Woolard

H6-03

R. D. Wojtasek

H6-05

M. T. York

57-84

Central Files (2)

H6-32

Document Clearance Administration (3)

L8-04 EPIC

H4-17

H6- 08 
WHC-MR-0418, REV 0

This page intentionally left blank. 